\title{
Meristematic activity of the Endodermis and the Pericycle in the primary thickening in monocotyledons. Considerations on the "PTM"
}

\author{
NANUZA L. DE MENEZES ${ }^{1}$, DELMIRA C. SILVA ${ }^{2}$, ROSANI C.O. ARRUDA ${ }^{3}$, \\ GLADYS F. MELO-DE-PINNA ${ }^{1}$, VANESSA A. CARDOSO ${ }^{1}$, NEUZA M. CASTRO $^{4}$, \\ VERA L. SCATENA ${ }^{5}$ and EDNA SCREMIN-DIAS ${ }^{6}$ \\ ${ }^{1}$ Universidade de São Paulo, Instituto de Biociências \\ Rua do Matão 277, Travessa 14, Cx. Postal 11461, Cidade Universitária, 05422-970 São Paulo, SP, Brasil \\ ${ }^{2}$ Universidade Estadual de Santa Cruz, Departamento de Biologia \\ Campus Soane Nazaré de Andrade, Km16, Rodovia Ilhéus-Itabuna, 45662-000 Ilhéus, BA, Brasil \\ ${ }^{3}$ Universidade Federal do Estado do Rio de Janeiro, Centro de Ciências Biológicas e da Saúde \\ Av. Pasteur 458, 22290-240 Rio de Janeiro, RJ, Brasil \\ ${ }^{4}$ Universidade Federal de Uberlândia, Instituto de Biologia \\ Campus Umuarama, Bloco 2D, Sala 28, 3840-902 Uberlândia, MG, Brasil \\ ${ }^{5}$ Universidade Estadual de São Paulo, Instituto de Biociências de Rio Claro, Departamento de Botânica \\ Av. 24A, 1515, Bela Vista, 13506-900 Rio Claro, SP, Brasil \\ ${ }^{6}$ Universidade Federal de Mato Grosso do Sul, Centro de Ciências Biológicas e da Saúde(CCBS, DBI) \\ Laboratório de Botânica, Cx. Postal 649, 74070-900 Campo Grande, MS, Brasil
}

Manuscript received on February 11, 2005; accepted for publication on February 16, 2005; contributed by NANUZa L. DE MENEZES*

\begin{abstract}
This paper proposes a new interpretation for primary thickening in monocotyledons. The anatomy of the vegetative organs of the following species was examined: Cephalostemon riedelianus (Rapataceae), Cyperus papyrus (Cyperaceae), Lagenocarpus rigidus, L. junciformis (Cyperaceae), Echinodorus paniculatus (Alismataceae) and Zingiber officinale (Zingiberaceae). The endodermis with meristematic activity was observed in the root of all the species, in the stem of Cyperus, Cephalostemum and Lagenocarpus rigidus, and in the leaf trace of Cyperus and leaf of Echinodorus. Considering the continuity of tissues through the root, stem and leaf, the authors conclude that in the stem the pericycle remains active throughout the life of the plant as the generator of the vascular tissue. The "Primary Thickening Meristem" is in fact the pericycle plus the endodermis and its derivatives (or only the pericycle). Close to the stem apex, the assemblage of seems to be a unique meristem, giving rise to the inner cortex and vascular tissues.
\end{abstract}

Key words: Cephalostemon, Cyperus, Echinodorus, Lagenocarpus, Zingiber, meristematic endodermis, pericycle, primary thickening.

\section{INTRODUCTION}

* Member Academia Brasileira de Ciências Correspondence to: Nanuza L. de Menezes E-mail: nanuzalm@usp.br
Since the $19^{\text {th }}$ Century, researchers have presented proposals in an attempt to understand the tissues that form the primary body of a monocotyledon stem, 
in particular, the limit zone between the cortex and the vascular cylinder. According to Mangin (1882), this zone has been given different denominations, such as the "pericambium", "perimeristem", "properimeristem", "generating zone", "couche dyctiogène", and "thickening ring". However, there has general agreement that this zone is made up of adventitious roots.

More recently, authors attempting to understand this region have admitted the presence of a primary thickening meristem (PTM), which is responsible for the primary thickening of the stem in virtually all monocotyledons, as Rudall (1991) clearly demonstrates in her revision work on the PTM. For the same author (Rudall 1991) and others (especially Cheadle 1937, DeMason 1979a, b, 1980, 1983, Stevenson and Fisher 1980, DeMason and Wilson 1985, Gifford and Bayer 1995), the function of promoting the formation of adventitious roots has also been attributed to the PTM.

Also according to Rudall (1991), some authors admit that the PTM corresponds to the pericyclic region of the stem. Tomlinson and Zimmermann (1969, p. 174) states, literally, that "The problem was to decide whether there was a region in the monocotyledonous stem, to which the term "pericycle" could be given. This is an entirely artificial concept, since in most monocotyledonous stems, the cortex and central cylinder each end where the other begins".

Another theme which has generated much polemic debate is the presence of the endodermis in the stem and leaves. In his extraordinary revision work, Van Fleet (1961) demonstrates, giving a wealth of data and details, the presence of the endodermis in these organs. According to this author, although in the root (and underground stems) it can be characterized by the presence of the Casparian strips, suberized walls or unilaterial deposits of cellulose in the aerial stems and leaves, it may or may not present Casparian strips and other characteristics, denominated "starch sheath", "bundle sheath", "border parenchyma" and "mestome sheath". However, these varied types of cells produce the same histochemical system, and all these cells develop or are induced to develop Casparian strips. Van Fleet (1961) admits, as a sine qua non condition, the endodermis as the inner cortex layer in the root, stem and petiole; and the inner layer of the mesophyll. The author draws attention to the fact that many authors denominate the endodermis as "endodermoid layer" when it presents Casparian strips in the stem and leaves, a term with which he does not agree.

Another aspect which has been somewhat neglected, is the radial disposition of the cortex cells of the roots of mono and dicotyledons, a radiation which originates in the cells of the endodermis. According to Mangin (1882), the root cortex of monocotyledons consists of two regions: the external region, with disorganized parenchymatous cells, and the internal region, with cells organized in radial rows. Of those who attempted to interpret these radial rows of cells, the pioneers were Williams (1947), Hurst (1956 apud Van Fleet 1961) and Van Fleet (1961).

Williams (1947), while studying the apical meristem, as well as the primary tissues in 74 species of monocotyledons and 105 species of dicotyledons, demonstrated the presence of a layer of cells, which he denominated the plerome, a layer which would later differentiate into the endodermis. Cortical cells in all the roots investigated were produced by the rapid division of this layer of cells, and the arrangement of the cortical cells in relationship to the endodermal layer, suggests the meristematic nature of this layer, functioning as a true cambium. Following the work of Williams (1947), Hurst (1956 apud Van Fleet 1961) describes the same type of division in Smilax as the results of a pro-endodermis, and hence Van Fleet (1961) refer to the endodermis as meristematic. Heimsch (1951), studying the development of vascular tissue in the roots of barley, mentions the works of Williams (1947), as being in agreement with his own. However, in the roots of Pisum sativum, this same layer was referred to as a proendodermal layer (Popham 1955), and again, more recently, in Trifolium (Mueller 1991), Hydrocharis morsus-ranae (Seago et al. 1999), and in Typha 
glaucai (Seago and Scholey 1999).

Urano and Menezes (1996), with Cephalostemon riedelianus, and Conceição and Menezes (1996), with Nymphoides indica, refer to these radiate layers as the result of "mother cells of the endodermis". On the other hand, Melo-de-Pinna and Menezes (2003) refer to these layers as being the results of meristematic activity of the endodermis, following Williams (1947) and Van Fleet (1961). Cheadle (1937), observes the presence of radiate growth in the cortex of the root in Dracaena goldieana, external to the intact endodermis, and names this radiate region a "secondary cambial zone". Guillaud (1878), referring to the same region also mentions a "meristem external to the endodermis", in reference to the same region of radiate cortical cells.

According to Cheadle (1937), there is no clear differentiation of tissues on the cauline apex, and it therefore seems impossible to detect which layer originates what he denominates as a "thickening ring". This could be the pericycle, which is generally accepted as being outermost layer of the stele, or possibly the endodermis, the innermost layer of the cortex.

The aims of this paper are to demonstrate:

(1) the continuity of tissues between the root, stem and leaf in monocotyledons;

(2) the pericycle as a generating layer of vascular tissues;

(3) the endodermis as having a meristematic function in the root, stem and leaf, combining to form part of the stem and root cortex and part of the leaf mesophyll, and

(4) to present a new hypothesis to explain growth in thickness in monocotyledons.

\section{MATERIALS AND METHODS}

Part of the material studied was collected in the gardens of the Department of Botany of the IBUSP: rhizomes of Cyperus papyrus L. (Cyperaceae), N. Menezes 1416, rhizome of Zingiber officinale Roscoe (Zingiberaceae), N. Menezes 1417; the vouchers were deposited in the departmental herbarium (SPF).

Rhizomes of Cephalostemon riedelianus Koern (Rapateaceae), N. Menezes 1347 b (SPF), and of Lagenocarpus rigidus (Kunth.) Nees (Cyperaceae), Vitta 690 (UEC), L. junciformis (Kunth) O. Kunth, Vitta 540 (UEC) were collected at Serra do Cipó (MG). Leaves of Echinodorus paniculatus Micheli (Alismataceae) were collected in Mato Grosso do Sul, E. Scremin-Dias s/n (SPF 136.463).

The rhizomes of Cephalostemon and Lagenocarpus, as well as the leaves of Echinodorus, were fixed in FAA (Johansen 1940); following dehydration in ethanol series, the material was conserved in ethanol 70\%. After inclusion in paraffin, histological sections varying from 10 to $15 \mu \mathrm{m}$ in thickness were prepared according to standard techniques (Sass 1951, Johansen 1940). Later, the sections were stained with astra blue and safranin (Bukatsch 1972), concomitant with a double staining of crystal violet and Orange G (Purvis et al. 1964). The slides were secured by sealing the cover slips with Canadian balsam.

The rhizomes of Cyperus and Zingiber were hand cut using a razor blade, and the cuts, after staining with astra blue and safranin (Kraus et al. 1998), were mounted in $33 \%$ glycerin. For suberin, Sudan IV was used.

\section{RESULTS}

The cortex in the root of Cyperus papyrus (Fig. 1-3) was found to be composed mostly of radiate rows of cells originating from the endodermis. After the divisions, which give rise to the derivatives of the meristematic endodermis (DME), (Fig. 3), thickening and lignification of the internal cortex cells occurs, and the endodermis acquires Casparian strips (Fig. 1 and 2). There is a complete continuity between the tissues of the root and those of the rhizome that gave rise to it (Fig. 4 and 5), and it can be observed that the layers of DME are also found to be thickened in the rhizome (Fig. 4). The pericycle is uniseriate. Continuity of the tissues between the root 


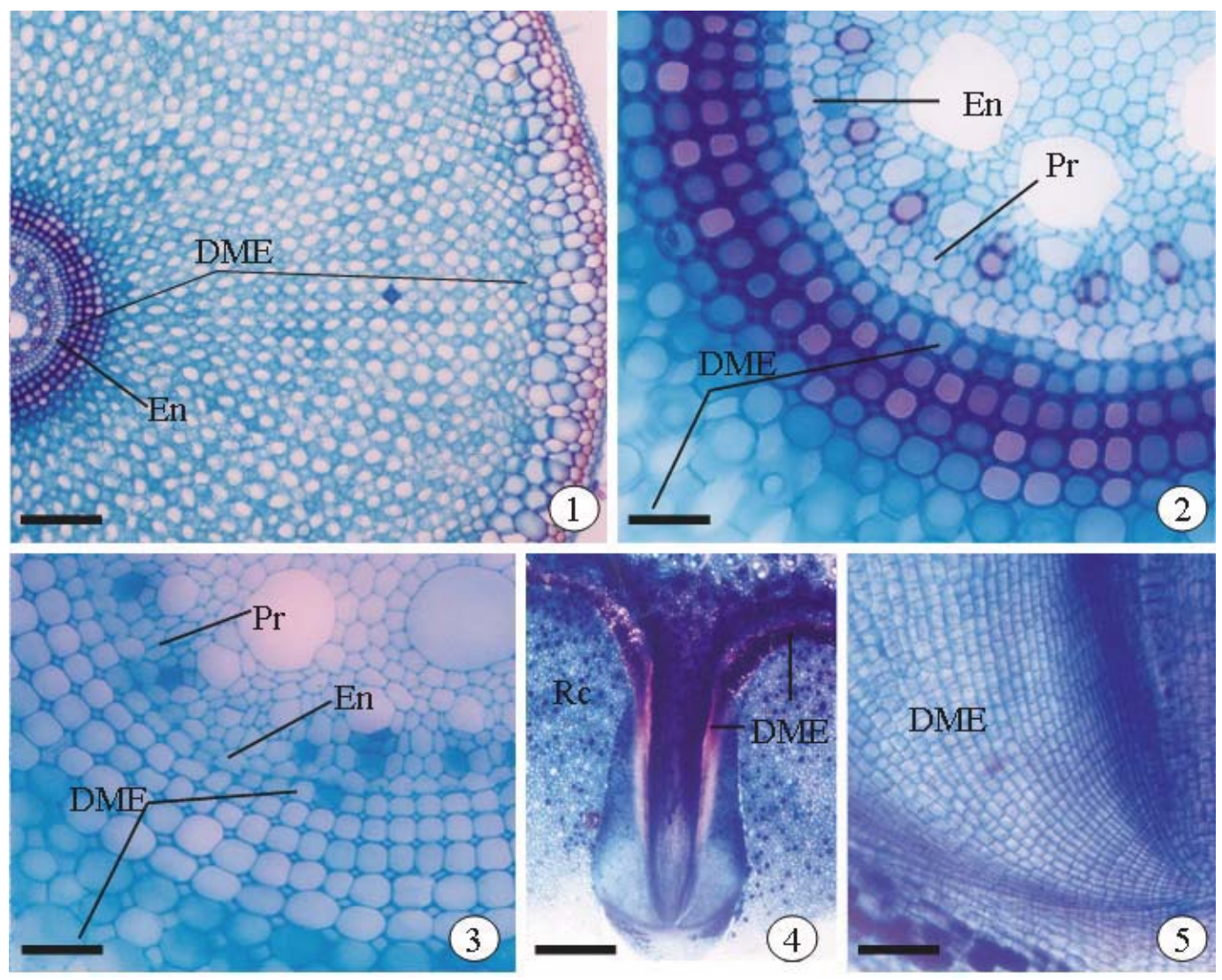

Fig. 1-5 - Cyperus papyrus. Root in transverse (1-3) and longitudinal (4 and 5) sections showing almost all the cortex with the placing of its radiate cells, originated by endodermal (En) activity, constituting the DME (Derivatives of Meristematic Endodermis). Note in Fig. 4, the tissue continuity between the root and the rhizome. The inner cortex is shown thickened at the root (Fig. 1,2 and 4) and in the rhizome (Fig. 4). The pericycle (Pr) is uniseriate. Rc - rhizome cortex. The bars correspond respectively to: $400 \mu \mathrm{m}, 100 \mu \mathrm{m}$, $100 \mu \mathrm{m}, 600 \mu \mathrm{m}$ and $40 \mu \mathrm{m}$.

and the rhizome can be better observed in Fig. 6-8. The layers of the DME which constitute the internal cortex of the rhizome appear with primary walls (Fig. 6-9). The pericycle was found to be adjacent and internal to the endodermis, and is multiseriate (Fig. 9). New vascular bundles can also be observed.

Initially, the endodermis exhibits Casparian strips, and later, the walls of the endodermal cells in contact with the pericycle (Fig. 9) can be seen to be suberized. Suberization extends to all the walls of the endodermal cells (Fig. 10, 11 and 13). In Fig. 10 the DME cells still show only primary walls, but, further away from the rhizome apex, secondary walls are acquired, which become lignified in a centripetal pattern. This lignification finally reaches the endodermal cells themselves (Fig. 14). At the point where the DME cells in the stem possess the primary walls, the leaf trace in the cortex also presents DME layers without lignification (Fig. 12), however when the former become lignified, the DME of the trace also appears lignified (Fig. 15). In those regions closer to the apex (Fig. 16 and 17), it is possible to verify endodermal initials dividing, and the beginning of the formation of DME layers. It is also possible to see the beginning of division of the pericycle (Fig. 16), placed between the endodermal initials and the procambium strands. In Fig. 17 it is possible to see the organization of a vascular bundle, which already (Fig. 18), exhibits differentiation of tracheal elements (although with only primary walls) and the endodermis, with imperceptible Casparian strips (indicated by arrows). In regions of 


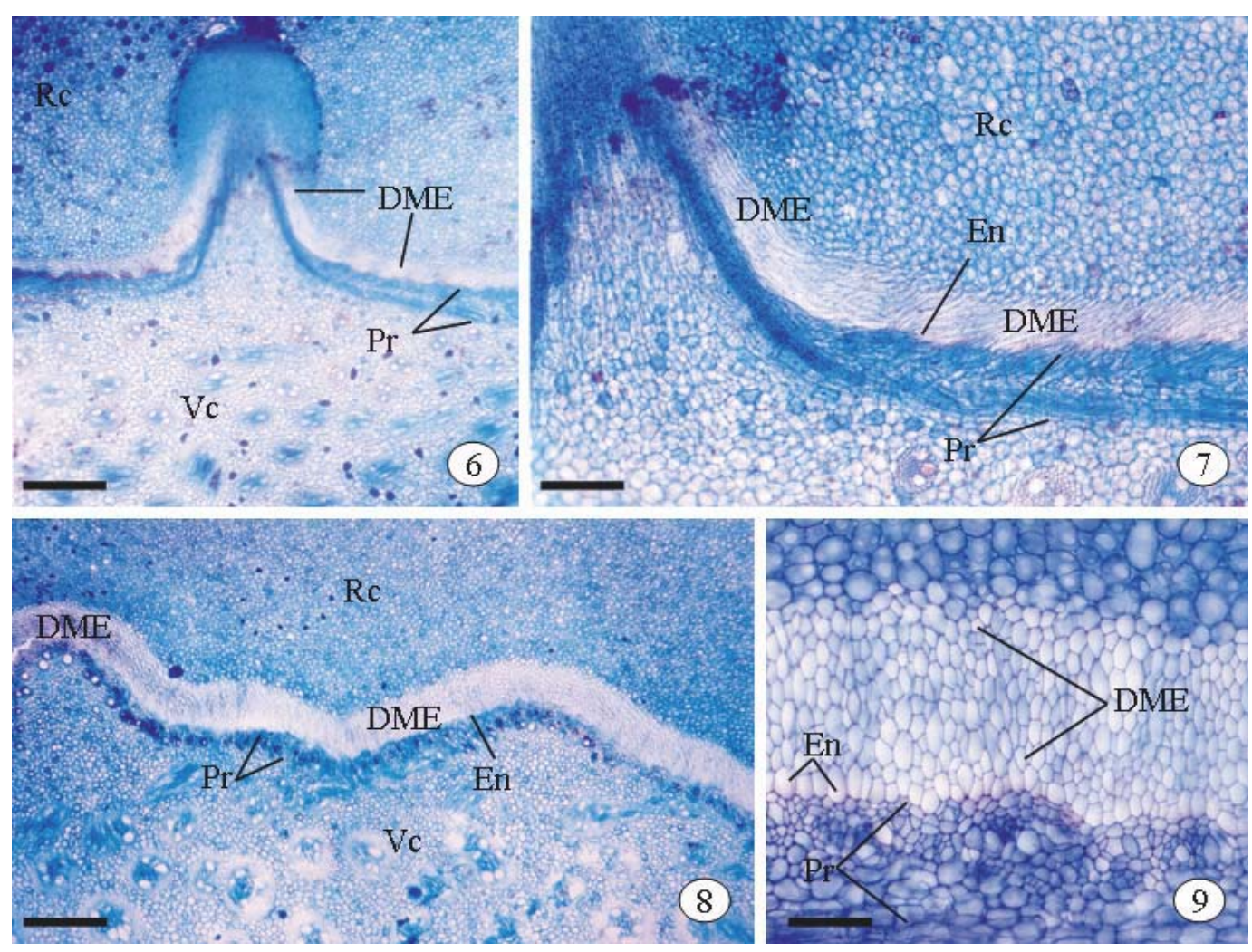

Fig. 6-9 - Cyperus papyrus. Transverse sections of the rhizome. Note (Fig. 6, 7 and 8) continuity of tissues between the root and the rhizome; the endodermis (En) in Fig. 7 appears with Casparian strips (arrow). The pericycle (Pr) appears as generating tissue of vascular tissues, especially in Fig. 9. DME - Derivatives of the Meristematic Endodermis; Rc - rhizome cortex; Vc - vascular cylinder. The bars correspond respectively to: $600 \mu \mathrm{m}, 400 \mu \mathrm{m}, 400 \mu \mathrm{m}$ and $100 \mu \mathrm{m}$.

the rhizome further from the apex, the inner cortex formed by the DME shows cells with thickened walls (Fig. 19), the pericycle being the generative layer.

In a longitudinal section of a bud of the rhizome of Lagenocarpus rigidus (Fig. 20 and 21), it can be noted that, near the apex (although the section is not median), the walls of the DME layer are not thickened, while those at the base are. The pericycle of the DME layers can be perfectly distinguished. In the region indicated by an arrow in Fig. 21, although formed by various layers of meristematic cells, it is possible to distinguish the pericycle from the endodermal initials (Fig. 22), by the lack of correspondence between the cells resulting from the two meristems, and by a slight thickening of the external wall of the pericycle cells (arrow). In a region further from the apex, this separation is more per- ceptible (Fig. 23).

In a longitudinal section of the rhizome of Cephalostemon riedelianus, as already seen in Lagenocarpus, it is observed that the DME layers are thickened at the base of the rhizome (Fig. 24 and 25), and where they are not thickened, they appear translucent under the microscope. The pericyclic region forms a peripheral plexus (Fig. 25). Continuity of the DME tissues between the adventitious root and the rhizome is perfectly visible (Fig. 26, 27 and 28), so that in Fig. 28 one can observe the radial rows of DME cells.

In Zingiber officinale the stem endodermis does not exhibit meristematic activity, and the pericycle, adjacent to the endodermis with Casparian strips, is clearly the generating layer for vascular tissues (Fig. 29 and 30). In Lagenocarpus rigidus, the endodermis exhibits meristematic activity in both the 

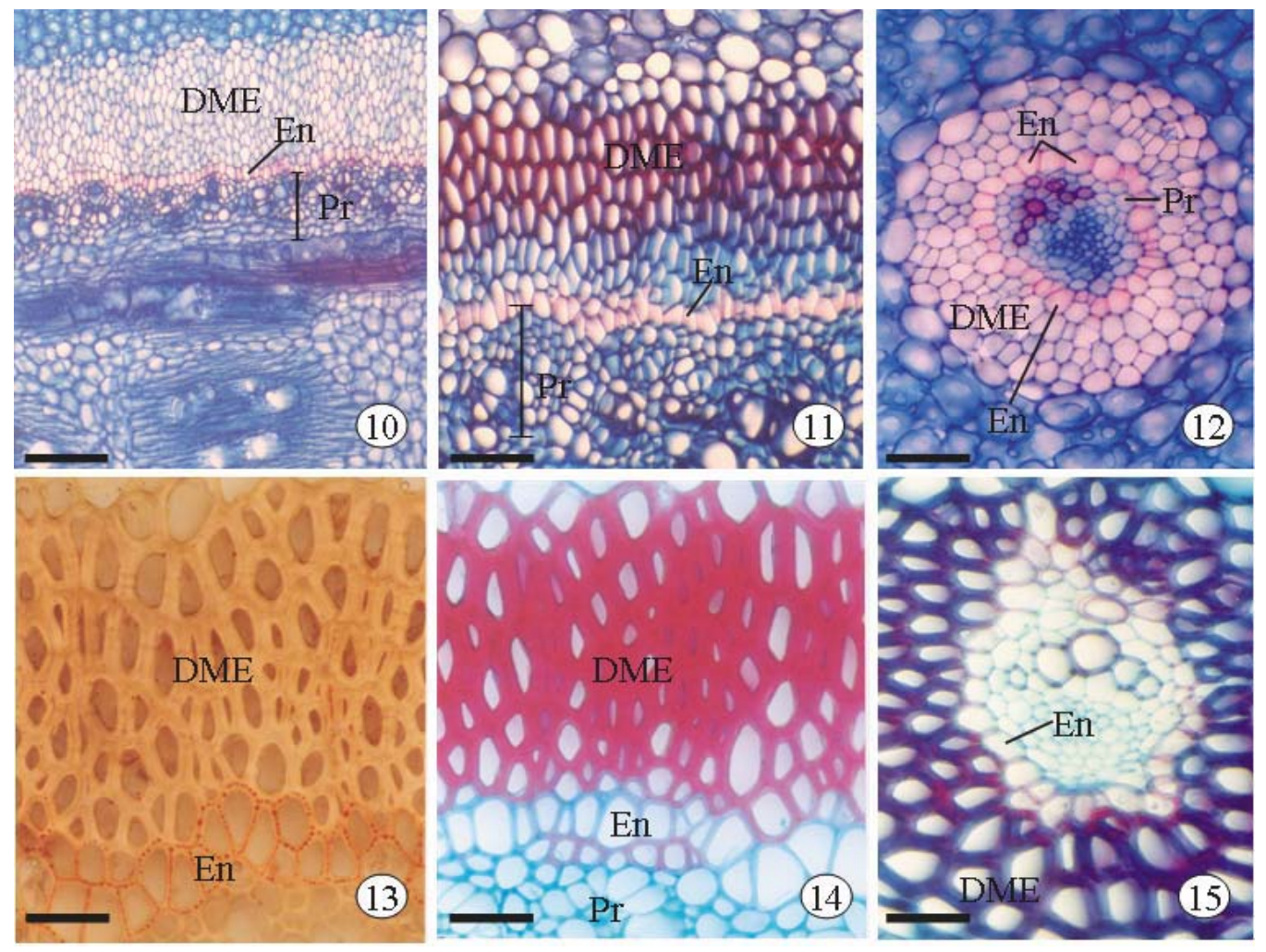

Fig. 10-15 - Cyperus papyrus. Different levels of transverse sections of the rhizome, one noting the endodermis (En) in Fig. 10, with suberize walls (better observed in Fig. 13). The DME (Derivatives of the Meristematic Endodermis) cells are not thickened (Fig. 10). At the level presented in Fig. 11, the progressive thickening of the walls of DME cells can be seen, and in Fig. 12, a leaf trace in the cortex of rhizome, at the corresponding level in Fig. 10, also presents derivatives of the meristematic endodermis (DME). Fig. 13 shows the result of the reaction with Sudan IV. Fig. 14 - Note the completely thickened DME layers, and at the same level, the leaf trace (Fig. 15) with thickened DME cells. Pr - pericycle. The bars correspond respectively to: $200 \mu \mathrm{m}, 100 \mu \mathrm{m}, 100 \mu \mathrm{m}, 50 \mu \mathrm{m}, 50 \mu \mathrm{m}$ and $50 \mu \mathrm{m}$.

adventitious roots and the rhizome, with the same type of centripetal thickening observed in Cyperus papyrus (Fig. 31). However in L. junciformis, the endodermis does not present meristematic activity in the rhizome (Fig. 32).

Meristematic activity is also found in the leaf, as can be seen in Echinodorus paniculatus, where endodermal initials can be distinguished (Fig. 33). These undergo periclinal divisions (Fig. 34) that will give rise to the DME layers (Fig. 35) which, in turn, will constitute a large part of the mesophyll (Fig. 36). After periclinal division of the endodermal initial cells ceases, these exhibit anticlinal divisions, which accompany the differentiation of the vascular system, where a uniseriate pericycle can be recognized.

\section{DISCUSSION}

Although a few authors refer to the presence of endodermis in the stem, almost none refer to the presence of the endodermis in the leaf, although Esau (1965), based on the work of Van Fleet (1961), states “... the bundle sheath of angiospermous leaves is an endodermis" (Esau 1965 - pg. 441). Most authors refer only to the "sheath of the leaf bundles", ignoring its origin. As for the meristematic activity of the endodermis, even Van Fleet (1961), in his admirable review of the endodermis, does not refer to meristematic activity in this tissue, either in the stem or the leaf. Van Fleet (1961), as well as all the authors quoted by him, including Williams (1947), refer only to the "cambial activity of the endodermis" 

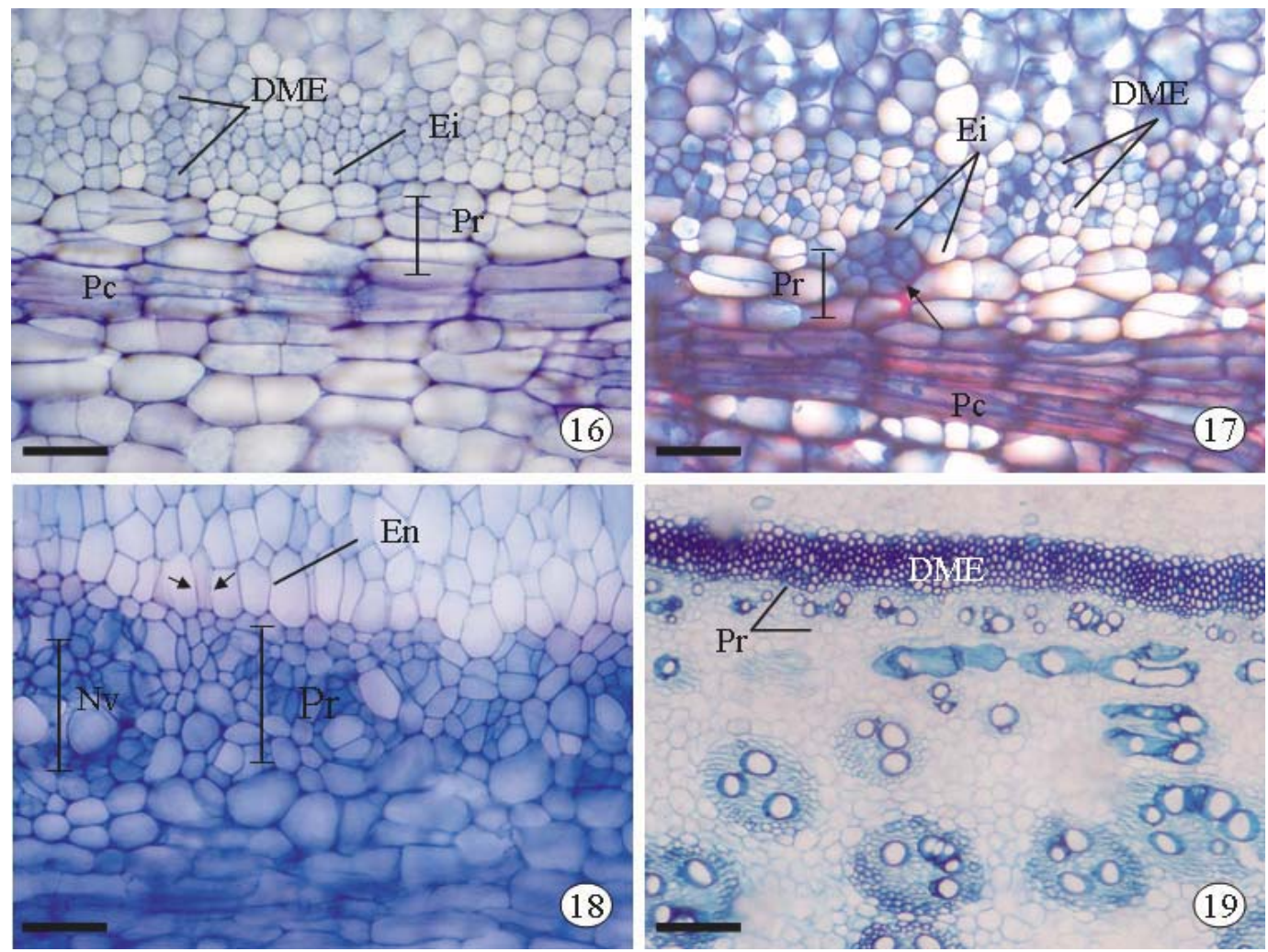

Fig. 16-19-Cyperus papyrus. Longitudinal (16 and 17) and transverse sections of the rhizome (18 and 19). Fig. 16 - The endodermal initial (Ei) is still in the division phase, and the pericycle (Pr) presents divisions in Fig. 17, which evidence differentiation of a vascular bundle (arrow). Fig.18 - Observe the endodermis already in differentiation, and adjacent to it, a new vascular bundle (Nv) originating in the pericycle (Pr). The arrows indicate imperceptible Casparian strips. Fig. 19-All of the inner cortex is thickened and the pericycle gives origin to bundles. DME - Derivatives of the Meristematic Endodermis. Pc - procambium. Rc - rhizome cortex; Vc - vascular cylinder. The bars correspond respectively to: $100 \mu \mathrm{m}, 100 \mu \mathrm{m}, 50 \mu \mathrm{m}$ and $400 \mu \mathrm{m}$.

in the root. In this work, we demonstrate the presence of this activity also in the stem and the leaf.

Here, we have verified the presence of radiate layers of cells constituting the cortex in the roots of both Cyperus and Cephalostemon. We agree with the proposal of Williams (1947) and Van Fleet (1961), that the endodermis possesses an activity similar to that of the cambium, since the same layer of dividing cells gives rise both to the remaining layer of initial cells, as well as to the derivative layer, which will constitute the next layer of the internal cortex. According to Williams (1947), after a certain number of divisions, the initials undergo differentiation, acquiring Casparian strips. Some recent authors (Seago and Scholey 1999), attribute the origin of the radial rows from a pro-endodermis, as proposed by Hurst (1956 apud Van Fleet 1961). We prefer to adopt the proposal of Williams (1947), even though we recognize that both proposals are the same.

The number of layers that make up the DME in the root varies from species to species, forming only the internal cortex, as in Richterago (Melo-de-Pinna and Menezes 2003) and Zingiber officinale, almost the whole cortex, as in Cyperus papyrus, Bacopa (Bona and Morretes 2003) and Iantopappus (Melode-Pinna and Menezes 2002), or the whole cortex, as in Nymphoides indica (Conceição and Menezes 1996) and Cephalostemon riedelianus (Urano and Menezes 1996).

According to Krauss (1948), the layer of cells in the stem, external to the vascular cylinder, has 

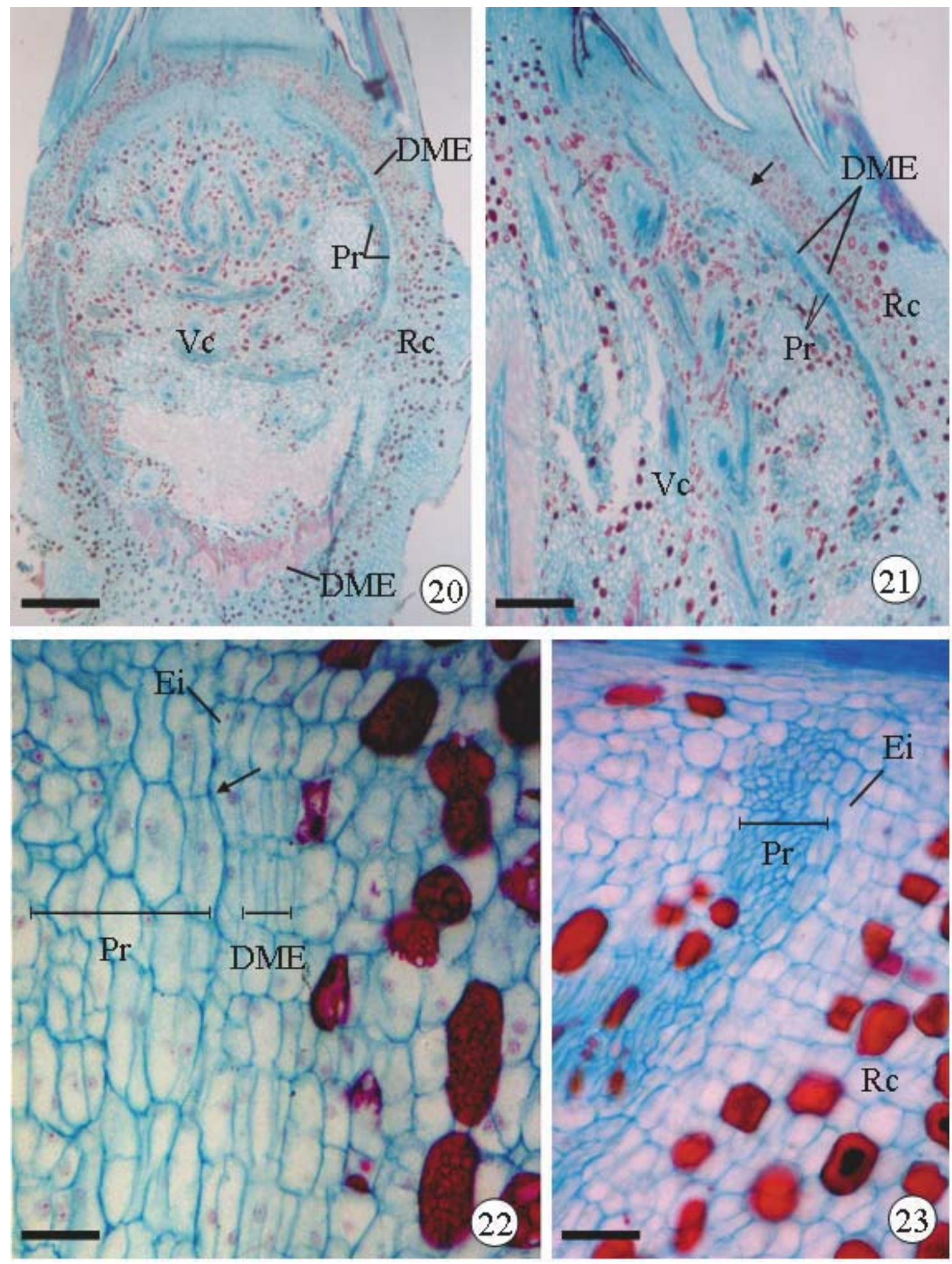

Fig. 20-23 - Lagenocarpus rigidus. Longitudinal sections of the rhizome. Note in Fig. 20 and 21 a distinct separation between the pericycle (Pr), which is the generating layer of vascular tissue, and the derivative layers of the meristematic endodermis (DME). In Fig. 21 the arrow indicates the region represented in Fig. 22. In Fig. 22, the arrow indicates the wall that separates the pericycle in its meristematic phase, from the endodermal initial (Ei), this being slightly more thickened. Note a gap between the outermost layers of the pericycle and the endodermal initials. Rc - rhizome córtex; Vc - vascular cylinder. The bars correspond respectively to: $600 \mu \mathrm{m}$, $400 \mu \mathrm{m}, 50 \mu \mathrm{m}$ and $100 \mu \mathrm{m}$. 


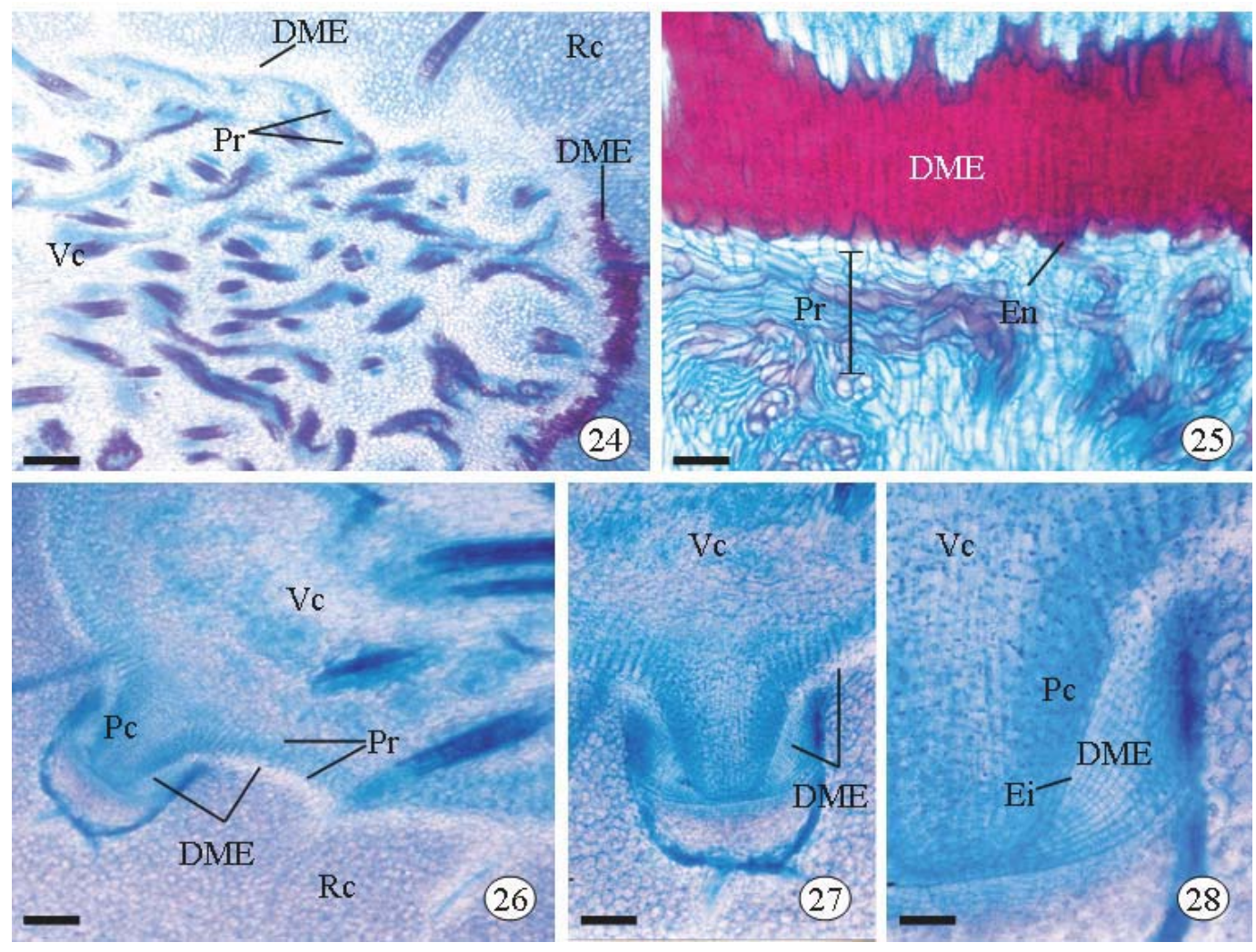

Fig. 24-28 - Cephalostemon riedelianus. Transverse sections of the rhizome, one showing in Fig. 24 the DME (Derivatives of the Meristematic Endodermis) layers presenting a translucid aspect when not thickened. Fig. 25 - Note the totally thickened DME layers, the inner cortex of the rhizome and the pericycle (Pr) comprising the generating layer of vascular tissues. Fig. 26 - Note the presence of an adventious root and the continuity between the DME of the root and the rhizome, better visualized in Fig. 27. Fig. 28 - Very distinct layers of cells that comprise the DME. Pc - procambium. Rc - rhizome cortex. Vc-vascular cylinder. The bars correspond respectively to: $600 \mu \mathrm{m}, 100 \mu \mathrm{m}, 400 \mu \mathrm{m}, 200 \mu \mathrm{m}$ and $100 \mu \mathrm{m}$.

been interpreted in various ways, but most authors consider it to be an endodermis, with the cells internal to it constituting the pericycle.

The same author (Krauss 1948) further states “... it is not surprising that so many authors describe the presence of both the endodermis and the pericycle in the stem of vascular plants, firstly, because it has traditionally been considered, in descriptions of monocotyledons, that if the stem is divided into cortex and stele, a pericycle and an endodermis limiting the stele at the edge must be present; and secondly, because on carrying out a superficial examination of the radial sections of the stem containing adventitial roots, the endodermal cells of these roots appear to be continuous with the endodermal cells of the stem". According to Krauss (l.c.), the pericycle is a potentially meristematic tissue.

The occurrence of an endodermis in rhizome of Cyperaceae has already been mentioned by several authors, including Roseck (1992 apud Gifford and Bayer 1995) in Cyperus esculentus, in which the author noted Casparian strips; Wills and Briscoe (1970) and Wills (1985), in Cyperus rotundus; Sharma and Mehra (1972), in Fimbrystilis; Govindarajalu (1974), in several other species of Cyperus; Rodrigues and Estelita (2003), in Cyperus giganteus; and Eiten (1969) in Eleocharis, in which she established that although she did not observe Casparian strips, she considered the endodermis easy to recognize due to the large size of its cells.

Certain authors do not unequivocally identify 

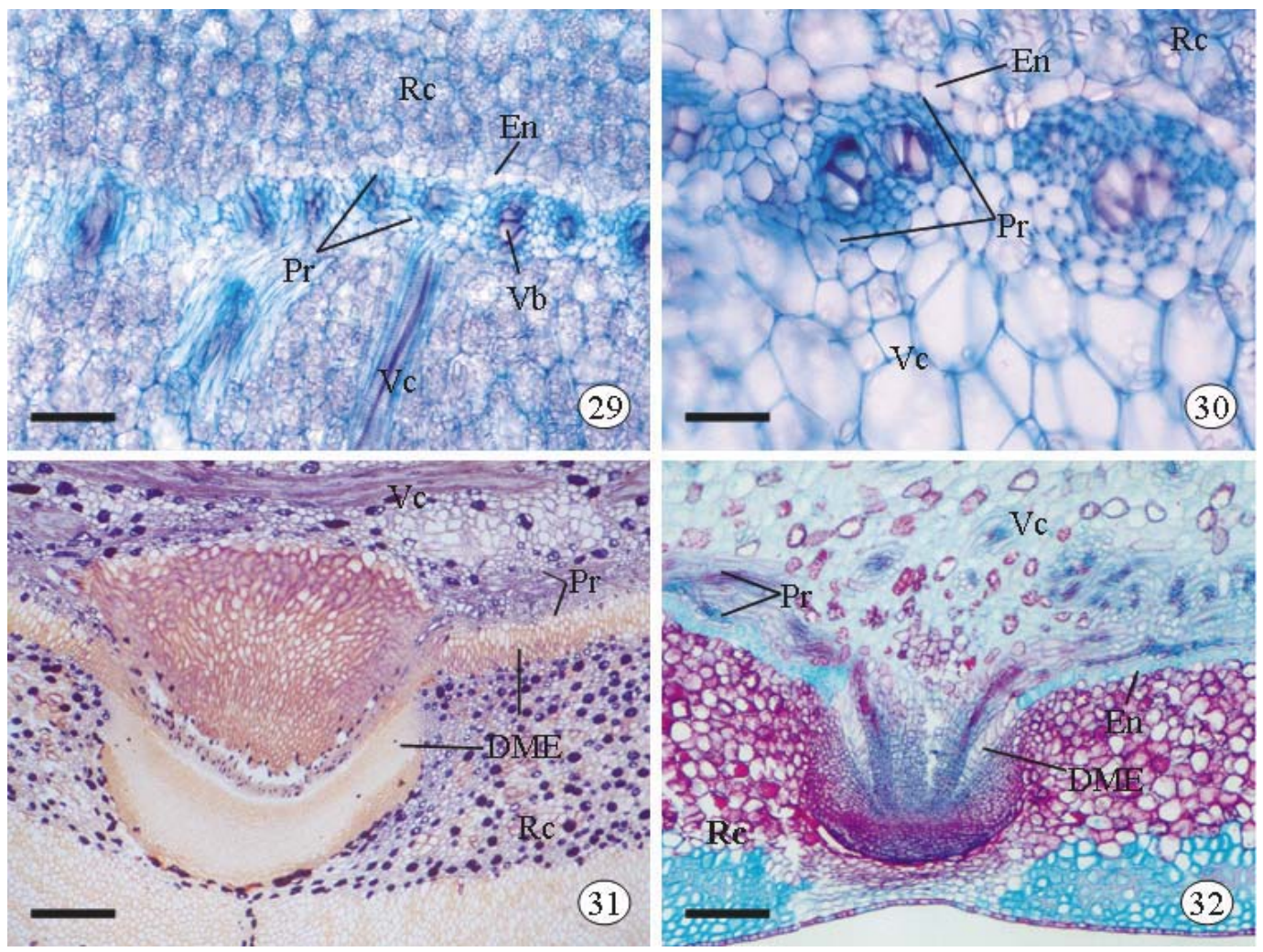

Fig. 29-32 - Transverse sections of the rhizome of Zingiber officinale (Fig. 29 and 30) and longitudinal sections of rhizomes of Lagenocarpus rigidus (Fig. 31) and L. junciformis (Fig. 32). In Zingiber the endodermis (En) has no meristematic activity, the generating layer being the pericycle (Pr). In Lagenocarpus rigidus the rhizome presents DME (Derivatives of the Meristematic Endodermis), whereas in L. junciformis the endodermis does not possess meristematical activity in the rhizome. Rc - rhizome cortex; $\mathrm{Vc}$ - vascular cylinder. The bars correspond respectively to: $200 \mu \mathrm{m}, 50 \mu \mathrm{m}, 400 \mu \mathrm{m}$ and $400 \mu \mathrm{m}$.

the innermost layer of the cortex of the rhizome in Cyperaceae as an endodermis, but prefer to call this the endodermoid layer (Kukkonen 1967, Metcalfe 1971), the endodermal sheath (Plowman 1906), or endodermoid cells (Gifford and Bayer 1995). Metcalfe (1971) makes it clear that he refers to this region, in the Cyperaceae, as the endodermoid layer, because the occurrence of Casparian strips has not been confirmed, even though he declares that he suspects their presence in younger cells.

We believe Van Fleet (1961) is correct when he says that the endodermis is not endodermis for the reason that it has Casparian strips or suberized cell walls, or any other characteristic, but because it is the innermost layer of the cortex in the root, stem and petiole, and the innermost layer of the leaf mesophyll.
In the cortex, in rhizomes of Cyperus papyrus, Lagenocarpus rigidus and Cephalostemon riedelianus, we demonstrate not only the presence of the endodermis, but also that of a stratified region of cells which, originating from this endodermis, constitutes the internal region of the cortex. In the same manner as in the root, we also denominate these stratified layers as DME (Derivatives of Meristematic Endodermis).

The results presented here for the rhizome of Cyperus papyrus demonstrate that after cell division starting from the endodermis has been completed, the cells acquire Casparian strips. After this phase, the endodermis cells become suberized. As the organ matures, it is observed that progressive thickening and lignification of the cell walls of DME takes place (similar to that which occurs in the internal 

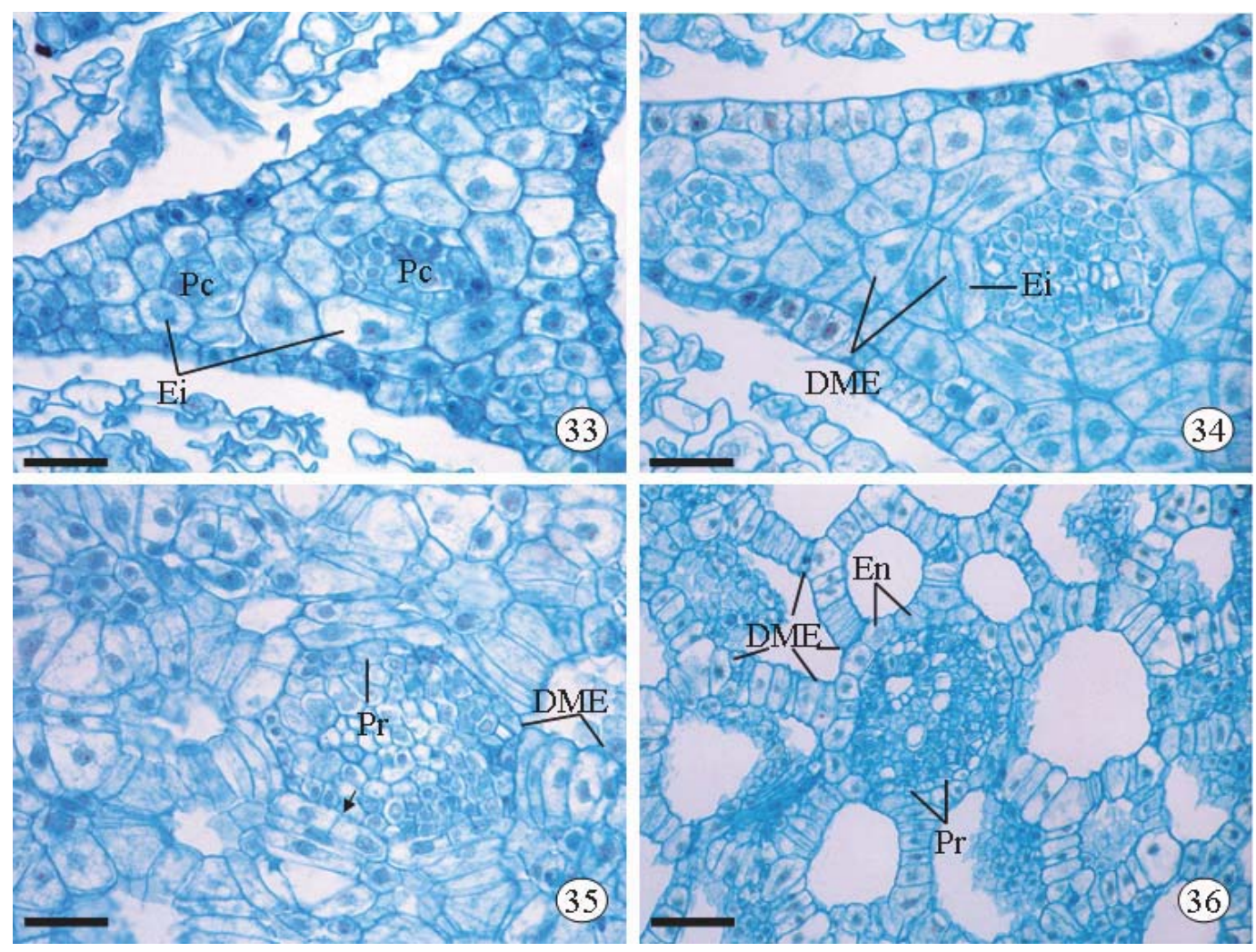

Fig. 33-36 - Echinodorus paniculatus. Leaves in differentiation, transversally cut, one showing in Fig. 33, endodermal initials (Ei) around the procambium $(\mathrm{Pc})$ of each future bundle. Fig. 34 - The endodermal initials presents periclinal division and its first derivatives to comprise the DME (Derivatives of the Meristematic Endodermis). Fig. 35 - Endodermal initial presenting anticlinal division. Fig. 36 - Endodermis already undergoing differentiation, the mesophyll aerenchyma cavities being enclosed by derivatives of endodermal activity. Pr - pericycle. The bars correspond to $50 \mu \mathrm{m}$.

cortex of the root), until the point is reached where the endodermis itself becomes thickened, as can be confirmed in the leaf traces. Thickening of the walls of DME cells in the stem and leaf trace go hand in hand.

This same type of endodermal division, as observed in the leaf traces of Cyperus papyrus, also occurs in leaves of Echinodorus paniculatus, where the cells, as a result of the meristematic activity of the endodermis, form a large part of the mesophyll, providing evidence of continuity between the tissues of the stem and the leaf.

It is this meristematic activity of the endodermis in the rhizome which, in our opinion, has confounded researchers who describe the primary thickening meristem (PTM) in monocotyledons. In the very young regions of the organ, in which the tissues are meristematic, the pericycle and the endodermis appear to form a single meristem. It is only through serial sections that it was possible to perceive, as in Lagenocarpus (Silva and Menezes 2000, in Silva 2000), that the endodermis forms layers of cells centrifugally, while the pericycle forms layers of cells centripetally. According to Williams (1947), in the root "... no mitotic figure has ever been found that could indicate that the meristematic endodermal layer gives origin to cells internally, or that the pericycle produces cells externally (except in the formation of lateral roots)". As we demonstrate in this work, this observation applies also to the stem.

In roots of Lagenocarpus rigidus and Cyperus papyrus, we have been able to confirm an observation to which Williams (1947) drew attention: 
a slight thickening of the wall separates the endodermal cell from the pericyclic one. This situation is also noted in Richterago, by Melo-de-Pinna and Menezes (2003).

It is important to point out that in certain groups, even though thickening of the organ occurs, cell division of the endodermis does not take place, as we have confirmed in the rhizome of Zingiber officinale, and in Lagenocarpus junciformis.

Both in species in which the presence of a meristematic endodermis has been noted, and in species in which the endodermis does not divide, the generating layer of vascular tissue (pericycle) is always situated internally to and contiguous with the endodermis. In our view, the generating layer of vascular tissue in monocotyledons is the pericycle, principally because this layer is always contiguous with the endodermis.

The presence of a pericycle is even less frequently mentioned, a fact which is demonstrated by Beiguelmann (1962) in the leaf of Erythroxylum, and by Menezes (1971) in Velloziaceae, through developmental studies and the tissue continuity between the stem and the leaf.

According to Van Tieghem (1898), there is a bundle-generating zone on the periphery of the stems of the Araceae, which he denominates the "generating zone", "occupying a part of the circumference in the genus Monstera, and complete in Acorus". According to this same author, this generating zone is always found totally encompassed by the endodermis.

On the other hand, Falkenberg (1876 apud Mangin 1882) established that "the most external layer of the central cylinder of the root, the pericambium, with its delicate walls, corresponds to the external layer of the central body of the stem of monocotyledons, mainly of the rhizome. And just as the pericambium of the root is the center for the formation of the lateral roots, in the same way, this layer of cells with delicate walls occupies the periphery of the central body of the rhizome, and is the tissue from which the adventitious roots are formed".

These observations by Falkenberg (1876 apud
Mangin 1882) are in exact agreement with our results presented here, in that the pericycle of the rhizome corresponds to the tissue which he denominates the "pericambium".

Mangin (1882) also states that Falkenberg criticizes the name "generating zone", which is given to this layer in Araceae by Van Tieghem (1898). We do not agree with this criticism, as we consider the name "generating zone" to be very appropriate for the pericycle.

Guillaud (1878) states that "in the stem of all monocotyledons, when the primitive (apical) meristem gives rise to the cortex, the medulla and the procambium strands, a generating zone appears at the limits of the cortex and the central body". The author describes this as a zone with light, translucent tissues involving the outermost bundles, and denominates it as the "perimeristem". In our opinion, he could have been referring to either the pericycle or to the derivatives of the meristematic endodermis, which appear translucent in section when not thickened. This has been noted here, in Cyperus papyrus and Cephalostemon riedelianus.

Evidence that it is possible to confuse the PTM with the endodermis with meristematic activity can be seen in the statement by Rudall (1991), that "the PTM often becomes lignified in older stems". The cells of both layers (the pericycle and the layers resulting from the meristematic endodermis - DME), by showing vacuolate cells at certain levels, exhibit cells with a translucent appearance, described by Fisher (1978) as the "light zone" in Musa, and by Rudall (1991) in her review of PTM and Secondary Thickening Meristem (STM). This observation corresponds to that of Krauss (1948) in which, in the oldest part of the stem of Ananas, the translucid region becomes lignified. In this work, we verified that it is really the layers resulting from endodermal activity (translucid layers), which form the internal cortex in stems, that becomes lignified in older rhizome.

Schat (1852 apud Mangin 1882) state that dividing cells situated between the medulla and the cortex are encountered in all vascular plants. These 
dividing cells he called the "cambial circle" or "thickening ring". This ring is more or less completely lignified in monocotyledons where the stem no longer thickens. However, when this activity continues, as in some monocotyledons, as is the case with the stem of Pandanus and Dracaena, considerable thickening can be achieved. Adventitious roots which develop are dependant on this tissue, which the author calls the "cambium". According to him, it is the same meristem that defines the form of the secondary body, and influences the development of lateral roots, shoots and leaves. We believe that the "cambial circle" of Schat corresponds to what we believe to be pericycle + endodermis with meristematic activity, and that the "thickening ring" corresponds, in fact, to layers resulting from the meristematic endodermis (DME), thickened as we have shown in Cephalostemon and Cyperus.

We also demonstrate here that in Cyperus papyrus, Cephalostemon riedelianus and Lagenocarpus rigidus, the DME layers thicken because in these plants, secondary growth does not occur. It is likely that same thing occurs with Xyris (Sajo and Rudall 1999), as well as Cyperus giganteus (Rodrigues and Estelita 2003), even though the last authors have described secondary growth in Cyperus giganteus.

Falkenberg (1876 apud Mangin 1882), in order to explain the separation of the stem into cortex and central cylinder, states: "in the stems of the monocotyledons, an internal mass of tissue is separated from an external mass, the cortex, this separation being frequently visible in transversal sections, by the formation of a limiting sheath". He admits that the origin of this sheath may be two-fold, that is to say, formed by the outermost cells of the central body and the innermost cells of the cortex. Our results lead us to agree with Falkenberg, as this region, which separates the cortex from the vascular cylinder, can be formed by the pericycle as well as the endodermis and its derivatives.

We believe that our results agree more with the "cap meristem" of Zimmermann and Tomlinson (1968) than with any other concept, even though these authors make no mention of the pericycle tissue and do not believe that "cap meristem" gives rise to vascular tissues. This is mainly because they not consider it to be identical to the PTM. On the other hand, the authors do not recognize the role of this meristem in primary thickening in Prionium.

From the results obtained here, any lingering doubt as to the presence of layers originating from meristematic activity of the endodermis in the stem must now be dispelled, in light of the evidence of the origin of adventitious roots, and the possibility of following the continuity of the tissues between the stem and the root. In the developing root, the vascular cylinder is completely continuous with the vascular system of the stem, just as the endodermis is perfectly continuous with the endodermis of the stem. The same occurs with its resulting layers (DME).

In Ananas comosus, Krauss (1948) noted the continuity of tissues between the root and the stem, without, however, admitting continuity between the endodermis of the root and that of the stem, through the non-detection of Casparian strips.

Although Gifford and Bayer (1995) demonstrate the same configuration in Cyperus esculentus, at no time do they mention the continuity of tissues between root and stem. Furthermore, based on the works of Gifford and Bayer (1995), particularly through observing figures 8, 12 and 16, it becomes clear that what these authors called PTM refers to the region here called DME.

As stated earlier, we have no doubt that primary thickening in monocotyledons occurs through the activity of the pericycle. Naturally, the first bundles in the stem apex are of procambial origin. The procambium gives origin to the pericycle, which remains active throughout the life of the plant as the generating tissue, as in Cyperus, Lagenocarpus and Zingiber. It is important to point out that the pericycle forms exclusively primary vascular tissue.

Through the work of Mangin (1882), it is observed that authors always refer to a generating layer of vascular bundle in monocotyledons, and that it is this layer, called variously the "pericambium", 
"perimeristem", "properimeristem", “couche dyctiogené", or other denominations, that generates the lateral roots in roots and adventitious roots in stems. In the present work, this layer is believed to be the pericycle. We believe that the plant is a unit, that the endodermis is present in the root, the stem and the leaf, and that the tissue internal to the endodermis is the pericycle in the root, the stem and the leaf. It is the pericycle which, as in the roots of dicotyledons forms the cambium in front of the protoxylem poles, in the stems of dicotyledons, forms the interfascicular cambium, in the stems of monocotyledons generates the meristem responsible for secondary thickening, i.e. the STM (Secondary Thickening Meristem).

Even authors such as Rudall (1984, 1991), who always make reference to the primary thickening meristem (PTM) in monocotyledons, admit that this meristem "occurs in the pericyclic region".

Some authors, such as Skutch (1932), Helm (1936 apud Rudall 1991), Krauss (1948) and Stevenson (1980) have described the PTM as a meristematic region continuous with the apical meristem. Actually, the meristematic pericycle is continuous with the apical procambium.

We once again state, from what can be seen in Cyperus, Lagenocarpus and Cephalostemon, that what these authors call the PTM is none other than the pericycle itself, or the pericycle + endodermis + DME.

According to Gifford and Bayer (1995), the PTM only produces cortical parenchyma and does not produce vascular tissue, however, judging from their illustrations, they were referring to what we here consider the DME. Baranetsky (1807 apud Cheadle 1937), on examining the development of several types of stem apices, established that "tissues of the cortex and the vascular cylinder could be composed of cells of different origins", which means that it would not only be the procambium that forms the stele, or only the fundamental meristem that forms the cortex.

In her review of PTM, Rudall (1991) states that most authors have established that "the PTM con- tributes to adventitious root production and the primary stem body - both centripetally and centrifugally".

We do not agree with these positions, which we declare to be mistaken, as it is only the fundamental meristem that forms the cortex, and the procambium which forms the primary vascular system; this in agreement with Robbins and Ricket (1939), Esau (1965, 1977), Fahn (1989), Mauseth (1995), Raven et al. (1999), and the $19^{\text {th }}$ Century European researchers mentioned earlier, among many others.

It is important to understand that the pericycle produce tissues centripetally and that the endodermis, with meristematic activity, produce tissues (DEM) centrifugally.

To summarize, the anatomical data obtained here strongly supports:

(1) the hypothesis that the "PTM" is none other than the pericycle itself or the pericycle + endodermis + DME;

(2) the pericycle (originating from the procambium) is the tissue that remains active throughout the life of the plant, giving origin to the vascular tissues;

(3) the endodermis can also have meristematic activity in the stem and leaf of monocotyledons.

\section{RESUMO}

A proposta deste trabalho é mostrar uma nova interpretação do meristema de espessamento primário em monocotiledôneas. Anatomia dos órgãos vegetativos das seguintes espécies foi examinada: Cephalostemon riedelianus (Rapataceae), Cyperus papyrus (Cyperaceae), Lagenocarpus rigidus, L. Junciformis (Cyperaceae), Echinodorus paniculatus (Alismataceae) and Zingiber officinale (Zingiberaceae). A atividade meristemática da endoderme foi observada nas raizes de todas as espécies, no caule de Cyperus, Cephalostemum e Lagenocarpus rigidus, e no traço foliar de Cyperus e folha de Echinodorus. Considerando a continuidade dos tecidos através da raiz, caule e folha, as autoras concluem que no caule o periciclo permanece ativo durante a vida da planta, como 
um gerador de tecidos vasculares. O "Meristema de Espessamento Primário" é o periciclo em fase meristemática, juntamente com a endoderme e suas derivadas (ou apenas o periciclo). Próximo ao ápice caulinar, esses tecidos se assemelham a um único meristema, dando origem ao córtex interno e aos tecidos vasculares.

Palavras-chave: Cephalostemon, Cyperus, Echinodorus, Lagenocarpus, Zingiber, endoderme meristemática, periciclo, espessamento primário.

\section{REFERENCES}

Beiguelmann B. 1962. Fibras do periciclo ramificadas no interior do mesófilo. Phyton 18: 127-131.

Bona C and Morretes BL. 2003. Anatomia das raízes de Bacopa salzmanii (Benth.) Wettst. ex Edwall e Bacopa monnierioides (Cham.) Robinson (Scrophulariaceae) em ambientes aquáticos e terrestres. Acta Bot Bras 17: 155-170.

BukAtsch F. 1972. Bemerkungen zur Doppelfärbung Astrablau-Safranin. Mikrokosmos 61: 255.

Cheadle VI. 1937. Secondary growth by means of thickening ring in certain monocotyledons. Bot Gaz 98: $535-556$.

Conceição AA And Menezes NL De. 1996. Características anatômicas de Nymphoides indica (L.) Kuntze. In Resumos: XLVII Congresso Nacional de Botânica, Nova Friburgo, RJ, 242 p.

DeMason DA. 1979a. Function and development of the primary thickening meristem in the monocotyledon, Allium cepa L. Bot Gaz 140: 51-66.

DeMason DA. 1979b. Histochemistry of the primary thickening meristem in the vegetative stem of Allium cepa. L Amer J Bot 66: 347-350.

DeMason DA. 1980. Localization of cell division activity in the primary thickening meristem in Allium cepa. L Amer J Bot 67: 393-399.

DeMason DA. 1983. The primary thickening meristem: definition and function in monocotyledons. Amer $\mathbf{J}$ Bot 70: 955-962.

DeMason DA and Wilson MA. 1985. The continuity of primary and secondary growth in Cordyline terminalis (Agavaceae). Can J Bot 63: 1907-1913.

EITEN LT. 1969. The vegetative anatomy of Eleocharis interstincta (Vahl) Roem. and Schult. Arqs Bot Est S. Paulo 4: 187-228.
Esau K. 1965. Plant Anatomy. $2^{\text {nd }}$ ed. John Wiley and Sons, New York.

EsAU K. 1977. Anatomy of seed plants. 2a. Ed., John Wiley and Sons. N. York.

FAhn A. 1989. Plant anatomy. 3a ed. Pergamon Press, São Paulo.

Fisher JB. 1978. Leaf-opposed buds in musa: their development and a comparison with allied monocotyledons. Amer J Bot 65: 784-791.

GiFFord EM AND BAYER DE. 1995. Developmental anatomy of Cyperus esculentus (Yellow nutsedge). In. J Plant Sci 156: 622-629.

Govindarajalu E. 1974. The systematic anatomy of south Indian Cyperaceae: Cyperus L. subgen. Juncellus, Cyperus subgen. Mariscus and Lipocarpha R. Br. Bot J Linn Soc 68: 235-266.

GuILlaud A. 1878. Rechersches sur l'anatomie comparée et le developpement des tissues de la tige dans les monocotylédones. Ann Sci Nat Bot Ser 6, 5: 1176.

Heimsch C. 1951. Development of vascular tissues in barley roots. Am J Bot 38: 523-537.

JoHANSEN DA. 1940. Plant microtechnique. New York, McGraw-Hill Book co. Inc.

Kraus JE, Souza HC, Rezende MH, Castro NM, VeCCHI C AND LuQue R. 1998. Astrablue and basic fuchsin double staining of plant materials. Biotec and Histochem 73: 235-2343.

KraUsS BH. 1948. Anatomy of the vegetative organs of the pineapple, Ananas comosus (L.) Merr. I. Introduction, organography, the stem, and the lateral branch or axillary buds. Bot Gaz 110: 159-217.

KUKKONEN I. 1967. Vegetative anatomy of Uncinia (Cyperaceae). Ann Bot 31: 523-544.

MANGIN L. 1882. Origine et insertion des racines adventives et modifications corrélatives de la tîge chez les monocotylédones. Ann Sci Nat Bot 14: 216-363.

Mauseth JD. 1995. Plant anatomy. Benjamin/Cumming Publising Company, Menlo Park.

Melo-de-Pinna GF and Menezes NL De. 2002. Vegetative organ anatomy of Iantopappus corymbosus Roque and Hind (Asteraceae-Mutisieae). Revista Brasil Bot 25: 505-514.

Melo-de-Pinna GF and Menezes NL de. 2003. Meristematic endodermis and secretory structure in ad- 
ventitious roots of Richterago Kuntze (MutisieaeAsteraceae). Revista Brasil Bot 26: 1-10.

Menezes NL DE. 1971. Traqueídes de transfusão no gênero Vellozia Vand. Cien Cult 23: 389-409.

MetCalfe CR. 1971. Anatomy of the monocotyledons. Vol. 5. Cyperaceae. Claredon Press. Oxford.

MuelLer RJ. 1991. Identification of procambium in the primary root of Trifolium pratense (Fabaceae). Am J Bot 78: 53-62.

Plowman AB. 1906. The comparative anatomy and phylogeny of the Cyperaceae. Ann Bot (London) 20: $1-37$.

PopHam RA. 1955. Levels of tissue differentiation in primary roots of Pisum sativum. Am J Bot 42: 529540.

Purvis MJ, Collier DC and Walls D. 1964. Laboratory techniques in botany. London, Butterworths.

Raven PH, Evert RF AND EichHoRn SE. 1999. Biology of Plants $6^{\text {th }}$ ed. W.H. Freeman and Company and Worth Publishers.

Robisns WJ and Ricket HW. 1939. Botany. $2^{\text {nd }}$ ed. D. Van Nostrand Company, New York.

Rodrigues AC and Estelita MEM. 2003. Primary and secondary development of Cyperus giganteus Vahl rhizome (Cyperaceae). Revista Brasil Bot 25: 259267.

RUdALl P. 1984. Taxonomic and evolutionary implications of rhizome structure and secondary thickening in Iridaceae. Bot Gaz 145: 524-534.

RUDALL P. 1991. Lateral meristems and stem thickening growth in monocotyledons. Bot Rew 57: 150-163.

Sajo MG and Rudall P. 1999. Systematic vegetative anatomy and ensiform leaf development in Xyris (Xyridaceae). Bot J Linn Soc 130: 171-182.

SAss JE. 1951. Botanical Microtechnique. Iowa State College Press, 228 p.

Seago JLJR ANd Scholey A. 1999. Development of the endodermis and hypodermis of Typha glauca Gord. And Typha angustifolia L. roots. Can J Bot 77: 122-134.

Seago JLJR, Peterson CA and Enstone DE. 1999. Cortical ontogeny in roots of the aquatic plant, Hydrocharis morsus-ranae L. Can J Bot 77: 113121.
Sharma OP and Mehra PN. 1972. Systematic anatomy of Fimbristylis Vahl (Cyperaceae). Bot Gaz 133: 87-95.

SiLVA DC. 2000. Anatomia dos órgãos vegetativos em espécies de Lagenocarpus Nees. (Cyperaceae) de campo rupestre. Doctorate Thesis, Institute of Biosciences, University of São Paulo.

Sкuтch AF. 1932. Anatomy of the axis of the Banana. Bot Gaz 93: 233-258.

Stevenson DW. 1980. Radial growth in Beaucarnea recurvata. Am J Bot 67: 476-489.

Stevenson DW and Fisher JB. 1980. The developmental relationship between primary and secondary thickening growth in Cordyline (Agavaceae). Bot Gaz 141: 264-268.

Tomlinson PB AND Zimmermann MH. 1969. Vascular anatomy of monocotyledons with secondary growth - an introduction. J Arnold Arbor 50: 159-179.

Urano MK and Menezes NL De. 1996. Aspectos anatômicos de órgãos vegetativos de Cephalostemon riedelianus Koern. Rapateaceae da Serra do Cipó - MG. In Resumos: XLVII Congresso Nacional de Botânica, Nova Friburgo, RJ, 240 p.

VAN FLEET DS. 1961. Histochemistry and function of the endodermis. Bot Rev 27: 165-221.

Van Tieghem PH. 1898. Éléments de Botanique. I Botanique Générale. 30 ed. Masson Et Cie, Paris.

Williams BC. 1947. The structure of the meristematic root tip and origin of the primary tissues in the roots of vascular plants. Am J Bot 34: 455-462.

WILls GD. 1985. Description of Purple and Yellow Nutsedge (Cyperus rotundus And C. esculentus). Weed Tech 1: 2-9.

Wills GD AND BRISCOE GA. 1970. Anatomy of purple nutsedge. Weed Sci 18: 631-635.

Zimmermann MH AND TomLinson PB. 1968. Vascular construction and development in the aerial stem of Prionium (Juncaceae). Am J Bot 55: 1100-1109. 